\title{
Head of the Epididymis
}

National Cancer Institute

\section{Source}

National Cancer Institute. Head of the Epididymis. NCI Thesaurus. Code C32717.

The first region of the epididymis distal to the testis. 